\title{
ADJUST OF REGRESSION MODELS TO ESTIMATE THE RECTAL TEMPERATURE OF BROILERS FOR THE FIRST 14 DAYS OF LIFE
}

\author{
PATRÍCIA F. PONCIANO ${ }^{1}$, TADAYUKI YANAGI JUNIOR ${ }^{2}$, RENATO R. DE \\ LIMA $^{3}$, LEONARDO SCHIASSI ${ }^{4}$, VITOR H. TEIXEIRA ${ }^{5}$
}

\begin{abstract}
The broiler rectal temperature $\left(\mathrm{t}_{\mathrm{rectal}}\right)$ is one of the most important physiological responses to classify the animal thermal comfort. Therefore, the aim of this study was to adjust regression models in order to predict the rectal temperature $\left(t_{\text {rectal }}\right)$ of broiler chickens under different thermal conditions based on age (A) and a meteorological variable (air temperature - $t_{\text {air }}$ ) or a thermal comfort index (temperature and humidity index - THI or black globe humidity index BGHI) or a physical quantity enthalpy $(\mathrm{H})$. In addition, through the inversion of these models and the expected $t_{\text {rectal }}$ intervals for each age, the comfort limits of $t_{\text {air }}$, THI, BGHI and $\mathrm{H}$ for the chicks in the heating phase were determined, aiding in the validation of the equations and the preliminary limits for $\mathrm{H}$. The experimental data used to adjust the mathematical models were collected in two commercial poultry farms, with Cobb chicks, from 1 to 14 days of age. It was possible to predict the $t_{\text {rectal }}$ of conditions from the expected $t_{\text {rectal }}$ and determine the lower and superior comfort thresholds of broilers satisfactorily by applying the four models adjusted; as well as to invert the models for prediction of the environmental $\mathrm{H}$ for the chicks first 14 days of life.
\end{abstract}

KEYWORDS: thermal environment, poultry, thermal comfort, mathematical modeling, physiological responses.

\section{MODELOS DE REGRESSÃO PARA A ESTIMATIVA DA TEMPERATURA RETAL DE FRANGOS DE CORTE DURANTE OS PRIMEIROS 14 DIAS DE VIDA}

RESUMO: A temperatura retal $\left(t_{\text {retal }}\right)$ de frangos de corte constitui uma das principais respostas fisiológicas para a classificação da condição de conforto térmico animal. Sendo assim, objetivou-se com este trabalho o ajuste de modelos de regressão para predizer a $t_{\text {retal }}$ de frangos de corte em diferentes situações térmicas ambientais, em função da idade (I) e de uma variável meteorológica (temperatura do ar - $t_{a r}$ ) ou de um índice de conforto térmico (índice de temperatura e umidade ITU, ou índice da temperatura do globo e umidade - ITGU) ou da grandeza física entalpia (H). Em adição, por meio da inversão desses modelos e dos intervalos de conforto esperados com base na $t_{\text {retal }}$ e idade, determinaram-se os limites de conforto de $t_{a r}$, ITU, ITGU e $\mathrm{H}$ para os pintinhos na fase de aquecimento, que auxiliaram na validação das equações ajustadas e na definição de limites preliminares para $\mathrm{H}$. Os dados experimentais utilizados para o ajuste dos modelos de regressão foram registrados em dois galpões comerciais, com aves da linhagem Cobb, de 1 a 14 dias de idade. Foi possível predizer, satisfatoriamente, a $t_{\text {retal }}$ de frangos de corte pelos quatro modelos gerados, bem como inverter os modelos para a predição das condições ambientais a partir da $t_{\text {retal }}$ esperada $e$ determinar, desta forma, os limites inferior e superior de conforto para a $\mathrm{H}$, para os primeiros 14 dias de vida do pintinho.

PALAVRAS-CHAVE: ambiente térmico, avicultura, conforto térmico, modelagem matemática, respostas fisiológicas.

\footnotetext{
${ }^{1}$ Zootecnista, Doutoranda em Engenharia Agrícola, Departamento de Engenharia,Universidade Federal de Lavras (UFLA), Lavras MG.

${ }^{2}$ Professor Associado I, Departamento de Engenharia, Universidade Federal de Lavras (UFLA), Lavras - MG.

3 Professor Adjunto III, Departamento de Ciências Exatas, Universidade Federal de Lavras (UFLA), Lavras - MG.

${ }^{4}$ Engenheiro Agrícola, Doutorando em Engenharia Agrícola, Departamento de Engenharia,Universidade Federal de Lavras (UFLA), Lavras - MG.

${ }^{5}$ Professor Associado, Departamento de Engenharia, Universidade Federal de Lavras (UFLA), Lavras - MG. 


\section{INTRODUCTION}

The thermal comfort inside poultry houses is a very important factor, since weather conditions can adversely affect the inadequate production of broilers (ROCHA et al., 2010). Among the environmental factors, the thermal are those that most directly affect the production, survival and welfare of the birds. Research has shown that the efficient management of environmental heating elements should ensure the maintenance of homeothermy of birds, especially in the initial growth phase of chickens (SANTOS et al., 2009).

The thermoregulatory device of birds is poorly developed, making them sensitive to cold as young and heat as adults (FUNCK \& FONSECA, 2008). If the temperature is below the thermal requirements of the birds, great part of the energy consumed in the diet, which could be used for production, is diverted to maintenance of the thermoregulatory system in the first weeks of life (CORDEIRO et al., 2010).

The relative humidity (RH) is also relevant for the confined animals, because it affects the thermal sensation. Generally, the heat is tolerable with a low rate of moisture, but it is not tolerable when the humidity is high. High values of relative humidity in a cold microclimate provide condensation of steam on the walls and other components of the shed, allowing the occurrence of diseases (MOURA et al., 2010). According to MEDEIROS et al. (2005a), the ideal is that the environment for growth of broiler chickens presents RH between 50 and $70 \%$.

An animal can demonstrate their comfort or discomfort through their physiological and productive, and can thereby be used to evaluate the efficiency of creating conditions and welfare of broiler chickens. The variables related to them suffer direct interference in the internal environment growth (DAMASCENO et al., 2010).

The increase in rectal temperature $\left(t_{\text {rectal }}\right)$ is a physiological response to conditions of air temperature $\left(\mathrm{t}_{\mathrm{air}}\right)$ and high $\mathrm{RH}$, which results in storage of metabolic heat (SILVA et al., 2003). To maintain body temperature relatively constant for the vital organs, the body heat must be stored or released in response to changes in the environment (FUNCK \& FONSECA, 2008). The birds maintain their body temperature through physiological and behavioral mechanisms (FURTADO et al., 2010). If these mechanisms are not sufficient to maintain homeothermy, the internal temperature increases and may, in extreme cases, occur deaths by animal thermal stress (MOURA et al., 2010).

The $t_{\text {rectal }}$ has great importance in their level of comfort or discomfort that the chicks are subjected, and the adjustment of the regression models for their estimation allows incorporation into based control systems, for example, in microcontrollers. Moreover, these equations can be used in hybrid models (mechanistic and empirical) to predict the partition of heat transferred between the birds and the environment around them.

In this context, the objective of this study is to adjust regression models to predict $t_{\text {rectal }}$ of broiler chickens in different thermal environmental conditions, according to age (A) and a weather variable (air temperature - $t_{\text {air }}$ ) or an index of thermal comfort (temperature and humidity index THI or black globe humidity index - BGHI) or the physical quantity enthalpy (H). In addition, through the inversion of these models and the ranges of comfort expected based on $t_{\text {rectal }}$ and age, it was determined the limits of comfort tair, THI, BGHI and $\mathrm{H}$ for the chicks in the heating phase, which helped to validate the adjusted equations and setting preliminary limits for $\mathrm{H}$.

\section{MATERIAL AND METHODS}

The data for the adjust of the regression models were recorded in an experiment conducted in two commercial broiler houses in the western of Minas Gerais, during the spring season of 2010.

The broiler house used, called A and B are oriented toward the northeast-southwest, away from each other about $100 \mathrm{~m}$. The averages geographic coordinates of the sheds are $20^{\circ} 12^{\prime} 02^{\prime \prime}$ south latitude and $45^{\circ} 02^{\prime} 08^{\prime \prime}$ west longitude of Greenwich. The average geographical coordinates of B 
broiler house are $20^{\circ} 11^{\prime} 58^{\prime \prime}$ south latitude and $45^{\circ} 02^{\prime} 08^{\prime \prime}$ west longitude of Greenwich. The two broiler houses are structurally identical, with $13 \mathrm{~m}$ wide, $160 \mathrm{~m}$ long and 3 feet ceiling height, roofing of asbestos cement $6 \mathrm{~mm}$ thick, concrete floor, bed of rice husk, side curtains and lining yellow plastic bag, positioned $2.45 \mathrm{~m}$ of height. It was used double curtains on the sides of the shed (one internal and one external). The curtains were drawn on the fifth day of life of the birds and the outside were managed according to the weather conditions throughout the experimental period. The area inside the broiler house was limited by the plywood sheets for the chicks to stay as close as possible to the heating systems. As the animals grew, these sheets were moved so that the area available to the animals could be increased. At the beginning of the experiment, on the first day of life, the birds were distributed at a density of approximately 54 birds $\mathrm{m}^{-2}$. Subsequently, the floor area of the building increased to reduce the density of housing, gradually, to the lodging density of 13 birds $\mathrm{m}^{2}$ at the end of the heating phase.

In the first broiler house, the heating system adopted consisted of two furnaces with biomass burning indirectly, built with handmade bricks, mud and dung on iron structure. The furnaces were located $80 \mathrm{~m}$ away from each other. Each furnace was $1.88 \mathrm{~m}$ long, $1.27 \mathrm{~m}$ wide and $1.58 \mathrm{~m}$ high. For its operation, used a three-phase motor, power $2206 \mathrm{~W}, 1725 \mathrm{RPM}$, which insufflate the air heated to the shed through a tube $10 \mathrm{~cm}$ in diameter.

In the B broiler house, the heating system consisted of an industrial furnace of metal material with indirect biomass burning, length $2.23 \mathrm{~m}$, width 1.23 and $1.85 \mathrm{~m}$ high. The heated air was blown by an AC motor, power $2206 \mathrm{~W}, 1725 \mathrm{RPM}$ and distributed by $28.6 \mathrm{~m}$ metal pipe on the northeast side and southwest side of the $22.45 \mathrm{~m}$ installed inside the broiler house. The pipe was 23 $\mathrm{cm}$ of diameter and holes with $5 \mathrm{~cm}$ of diameter placed alternately $1.0 \mathrm{~m}$ apart on each side of the pipe to the heated air outlet.

It was used 28,000 Cobb male chicks from 1 to 14 days old in each house. Data from the eighth day of the experiment were discarded because of a power outage occurred on the farm that day, making it impossible to manage and record data in broiler houses.

During the experimental phase, the birds had access to water ad libitum. The diets provided to the animals were formulated to meet nutrient requirements for different stages of growth and were equal for both systems.

To characterize the thermal environment, data were taken daily of $t_{a i r}$, dew point temperature $\left(t_{d p}\right)$, relative humidity and black globe temperature $\left(t_{\mathrm{bg}}\right)$. The position of the sensors changed as the placement of the sheets of plywood were changed so that the sensors register the condition in which the birds were submitted, as illustrated in Figure 1. Given that W is the width of the available area for birds and $\mathrm{L}$ is the length.

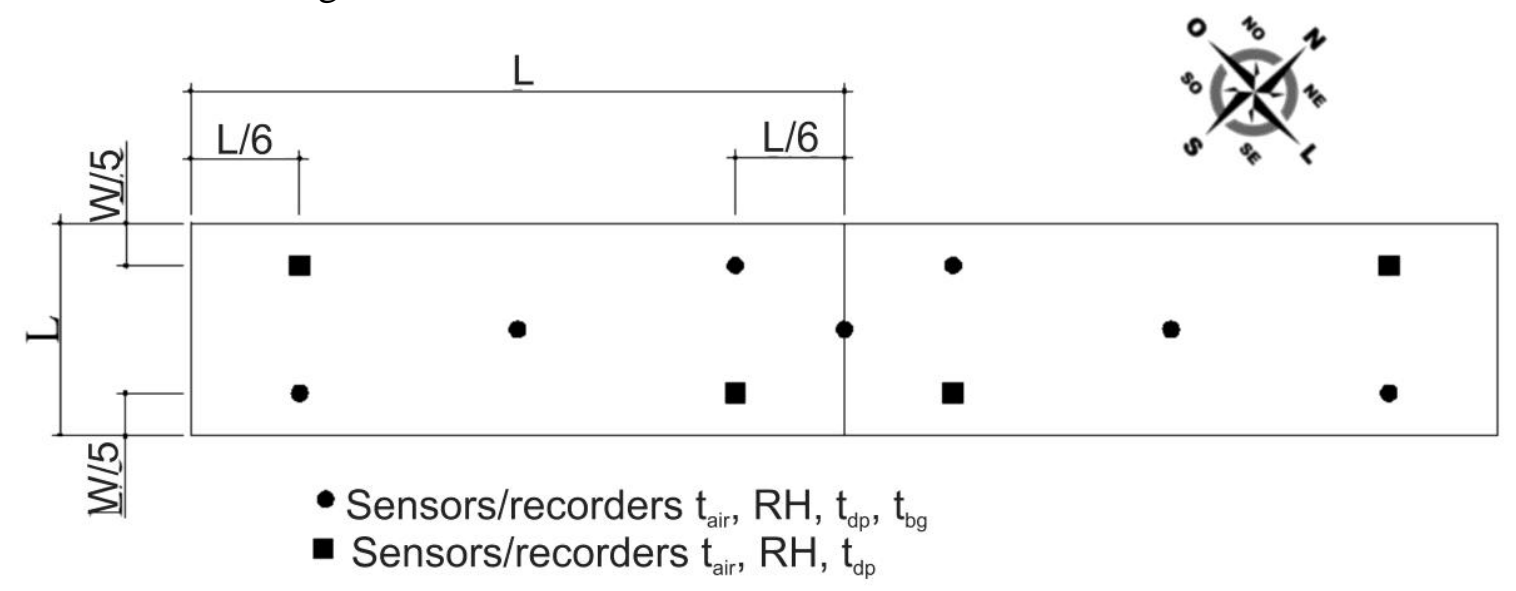

FIGURE 1. Data loggers position for measuring air temperature $\left(\mathrm{t}_{\text {air }}\right)$, relative humidity $(\mathrm{RH})$, dew point temperature $\left(t_{\mathrm{dp}}\right)$ and black globe temperature $\left(\mathrm{t}_{\mathrm{bg}}\right)$ in broiler units. 
Measurements were taken at a compatible height with the area occupied by the birds, from $10.0 \mathrm{~cm}$ of the bed (CORDEIRO et al., 2010), in five minute intervals throughout the experimental period. It was used sensors / recorders, Hobo Pro Series model, by the manufacturer Onset $₫$, with an accuracy of $\pm 3 \%$ of reading, kept in cages of wire mesh so the animals do not damage them.

The $\mathrm{t}_{\text {rectal }}$ was assessed 3 times a day during the periods $\mathrm{P} 1$, from $8 \mathrm{am}$ to $11 \mathrm{am}, \mathrm{P} 2,1: 40 \mathrm{pm}$ to $3: 20 \mathrm{pm}$ and $\mathrm{P} 3$ from $4: 30 \mathrm{pm}$ to $6: 20 \mathrm{pm}$. In each period, four birds in each broiler house were selected randomly and their rectal temperature measured. So every day, 12 birds were evaluated in each shed. The $t_{\text {rectal }}$ was measured using a digital thermometer INSTRUTEMP GUL term 200, $0.5 \%$ precision, with measurement range from -40.0 to $+700.0^{\circ} \mathrm{C}$. The sample size was defined as the time required and available for collection.

The environment inside the broiler houses was characterized by means of $t_{\text {air }}$, the temperature and humidity index (THI), the black globe humidity index (BGHI) and enthalpy (H).

By involving a smaller number of variables, the THI is one of the simplest indexes and has stood out for including the effects of $t_{\text {air }}$ and $\mathrm{RH}$. In this study, the index was calculated by an equation developed by THOM (1959).

$$
\mathrm{THI}=\mathrm{t}_{\mathrm{air}}+0.36 \cdot \mathrm{t}_{\mathrm{dp}}+41.5
$$

In which,

$$
\begin{aligned}
& \mathrm{t}_{\mathrm{air}}=\text { air temperature }\left({ }^{\circ} \mathrm{C}\right), \\
& \mathrm{t}_{\mathrm{dp}}=\text { dew point temperature }\left({ }^{\circ} \mathrm{C}\right) .
\end{aligned}
$$

The BGHI is currently the most widely used index for predicting thermal comfort in hot regions by incorporating the $\mathrm{t}_{\mathrm{air}}, \mathrm{RH}$, wind speed $(\mathrm{W})$ and radiation in the form of $\mathrm{t}_{\mathrm{bg}}$ into a single value, calculated by equation 2, developed by Buffington et al. (1981). The $\mathrm{t}_{\text {air }}, \mathrm{W}$ and radiation are quantified in the BGHI through $t_{\mathrm{bg}}$, due to heat exchanges by convection and radiation that occur between the black globe and the environment around it and the RH is quantified by the $t_{\mathrm{dp}}$.

$$
\mathrm{BGHI}=\mathrm{t}_{\mathrm{bg}}+0.36 \cdot \mathrm{t}_{\mathrm{dp}}-330.08
$$

In which,

$\mathrm{t}_{\mathrm{bg}}$ is the black globe temperature, $\mathrm{K}$, and

$\mathrm{t}_{\mathrm{po}}$ is the dew point temperature, $\mathrm{K}$.

According to BARBOSA FILHO et al. (2007a), enthalpy $(\mathrm{H})$ has been proposed to assess the internal environment of the broiler houses. By definition, $\mathrm{H}$ is a physical variable that indicates the amount of energy contained in a mixture of water vapor and dry air $\left(\mathrm{kJ} \mathrm{kg}^{-1}\right.$ dry air). Therefore, in cases of change in RH for the same $t_{\text {air }}$, the energy involved in this process is altered, and as a result, heat exchange in the environment will change. In this study, it was used the third equation, proposed by ALBRIGHT (1990), which according to RODRIGUES et al. (2010) is the most suitable for studies in animal environment.

$$
\mathrm{H}=1.006+\mathrm{W} \times\left(2501+1.805 \times \mathrm{t}_{\text {air }}\right)
$$

In which,

$\mathrm{H}$ is the enthalpy in $\mathrm{kJ} \mathrm{kg}^{-1}$ dry air

$\mathrm{W}$ is the mixing ratio, in $\mathrm{kJ} \mathrm{kg}^{-1}$ dry air

Multilinear regression models were adjusted for the estimation of the $t_{\text {rectal }}$ as a function of of the birds age and of the environmental data $\left(\mathrm{t}_{\mathrm{air}}\right.$, THI, BGHI and $\left.\mathrm{H}\right)$ recorded during the 40 minutes prior to the time of animals $t_{\text {rectal }}$ measurements and later, it was calculated the average of these data. This was done to have knowledge of the environmental changes that may have influenced the 
$\mathrm{t}_{\text {rectal }}$ in 40 minutes prior to the filing. The generic model of multilinear regression is represented by equation 4:

$$
\hat{Y}=b_{0}+b_{1} X_{1}+b_{2} X_{2}+\cdots+b_{k} X_{k}
$$

In which,

$\hat{\mathrm{Y}}=$ Estimate of the dependent variable (in this paper is the $\mathrm{t}_{\text {rectal }}$ ),

$b_{0}, b_{1} \ldots b_{k}=$ Regression coefficients, $\mathrm{H})$.

$\mathrm{X}_{1}, \mathrm{X}_{2}, \ldots \mathrm{X}_{\mathrm{k}}=$ Independent variables (in this study is that age and the $\mathrm{t}_{\mathrm{air}}$ or THI or BGHI or

Validation of regression models was performed by comparing the estimated $t_{\text {rectal }}$ values with measured and also the inversion of these models in order to verify that the ranges of $t_{\text {air }}$, THI, BGHI and $\mathrm{H}$ coincide with those recommended by literature. The inversion of multilinear regression models were performed according to the method described by DRAPER \& SMITH (1981), according to equation 5 :

$$
\left\{-Y_{0}+b_{0}+b_{1} X_{1}+b_{2} X_{2}+\cdots+b_{k} X_{k}\right\}^{2}=t^{2} s^{2}\left\{\left(1, X_{1}, X_{2}, \cdots X_{K}\right)\left(X^{\prime} X\right)^{-1}\left[\begin{array}{c}
1 \\
X_{1} \\
X_{2} \\
\vdots \\
X_{K}
\end{array}\right]\right\}
$$

In which,

$t=t(v, 1-\alpha / 2)$, where $v$ is the number of degrees of freedom of $s^{2}$.

Both regression models, as the inversion of multilinear regressions were performed using $\mathrm{R}$ software (R DEVELOPMENT CORE TEAM, 2007).

\section{RESULTS AND DISCUSSIONS}

\section{Thermal environment}

Figure 2 shows the values of $\mathrm{t}_{\mathrm{air}}$, THI, BGHI and $\mathrm{H}$ inside the two broiler houses throughout the experimental period and also the ideal ranges of these variables recommended by the literature, except for $\mathrm{H}$.

The ranges of $t_{a i r}$ considered comfortable for the broiler raising in the first and second weeks of life of the birds are between 32 and $34^{\circ} \mathrm{C}$ and between 28 and $32^{\circ} \mathrm{C}$, respectively (OLIVEIRA et al., 2006).

By observing Figure $2 \mathrm{~A}$, it can be seen that the $1^{\text {st }}$ and $2^{\text {nd }}$ days of life, even with the heating, the average temperature in the two broiler houses was much lower than recommended for the chicks raising. This low temperature is due to the failure of maintenance or management of heating systems, making it not to reach maximum efficiency necessary.

In the following days, this fault was corrected and the temperature was closer to the ideal for this age group. Only on the $9^{\text {th }}$ day of the birds' life, the temperature was slightly above the recommended, with a median of $33.6^{\circ} \mathrm{C}$. According to CORDEIRO et al. (2010), the first two weeks of the birds' life are the most critical, because mistakes made at this stage can not be corrected to the success in the future. Thus, the thermal environment at this stage must be carefully controlled to not adversely affect the final performance of the birds.

The variation of THI during the 14 days of experiment is illustrated in Figure 2B. ABREU \& ABREU (2001) recommend that the THI for broilers is 72.4 to 80 and 68.4 to 76 in the first and second weeks of life, respectively. Analyzing Picture $2 \mathrm{~B}$, it is observed that in the $1^{\text {st }}$ and $2^{\text {nd }}$, the THI was within recommended levels. But on all other days, the THI was above the ideal, featuring 
environmental discomfort and being able to impair growth and productivity of birds (ROCHA et al., 2010).

The behavior of BGHI throughout the experimental period is illustrated in Figure 2C. For birds, OLIVEIRA et al. (2006) considered comfortable BGHI values from 80.99 to 81.61 on the $1^{\text {st }}$ day of life, from 79.09 to 80.91 , from the $2^{\text {nd }}$ to the $4^{\text {th }}$ day; 77.00 , from the $5^{\text {th }}$ to $6^{\text {th }}$ day and 73.25 to 76.55 , from the $7^{\text {th }}$ to the $14^{\text {th }}$ day. Referring to Figure $2 \mathrm{C}$, it is noticed that on the $1^{\text {st }}$ day of the experiment, BGHI was lower than indicated, in the $2^{\text {nd }}$ day, was within the comfort and on other days, was always above the ideal.
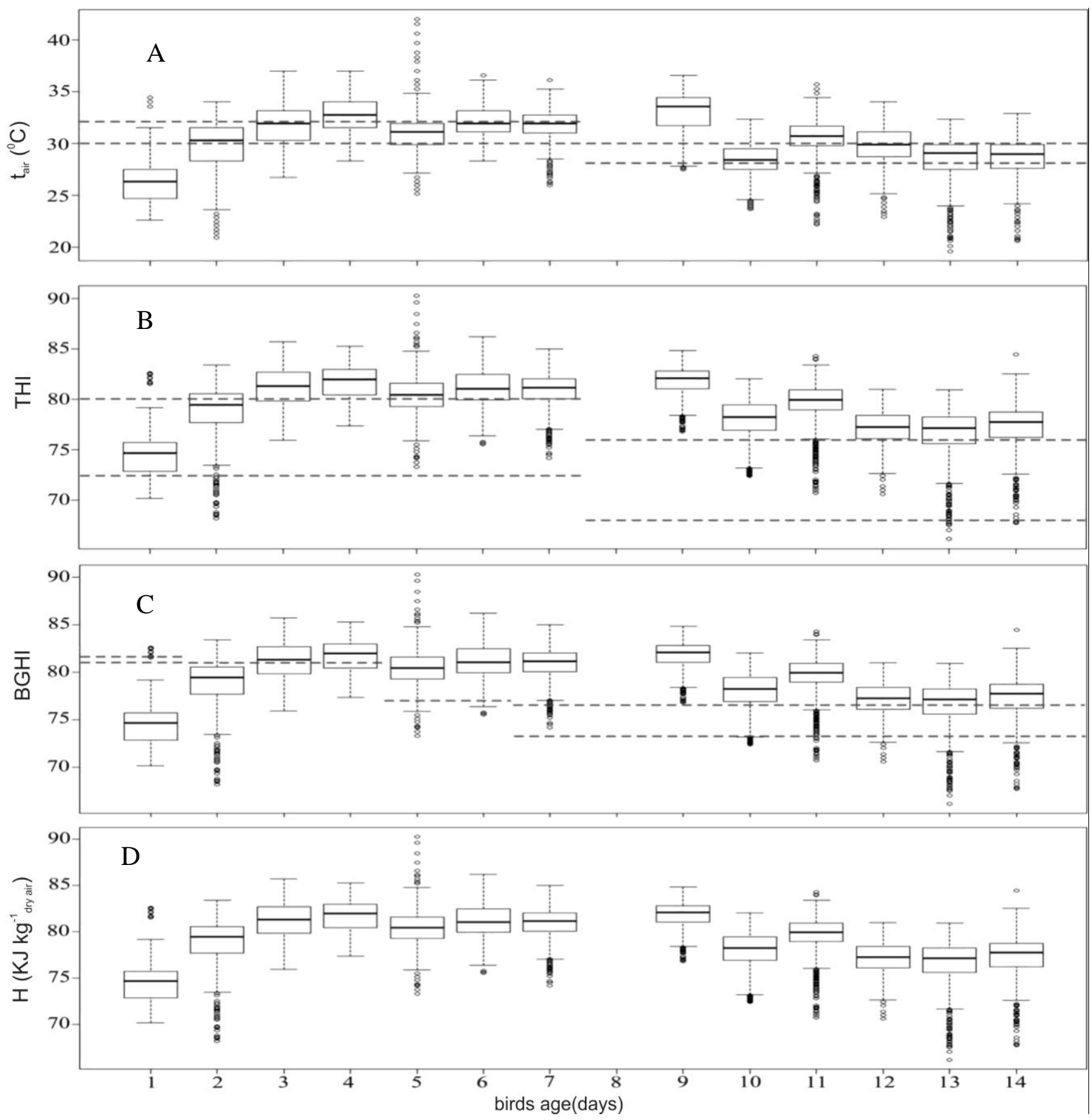

FIGURE 2. Box-plot for $t_{\text {air }}(A)$, THI (B), BGHI (C) and H (D) measured 40 minutes before the measurement of $t_{\text {rectal }}$ for the experimental period and their ideal intervals as recommended by the literature (dashed lines).

Figure 2D illustrates the $\mathrm{H}$ during the 14 days analyzed, however, the limits of thermal comfort were not added in the absence of this information in the literature. BARBOSA FILHO et al. 
(2007b) proposes limits from 80.0 to $86.6 \mathrm{~kJ} \mathrm{~kg}^{-1}$ dry air and 73.0 to $79.8 \mathrm{~kJ} \mathrm{~kg}^{-1}$ dry air in the first and second weeks, respectively, considering the equation developed by the same authors. According to RODRIGUES et al. (2010), this equation differs from that proposed by ALBRIGHT (1990) because it underestimates the true values of enthalpy.

\section{Regression models}

Four regression models to estimate the $t_{\text {rectal }}$ as a function of age and BGHI or $t_{\text {air }}$ or THI or $\mathrm{H}$ were adjusted (Equations 6, 7, 8 and 9, respectively). The four adjusted models were statistically significant ( $\mathrm{F}$ test, $\mathrm{P}<0.01$ ), and its coefficients were also statistically significant (t test, $\mathrm{P}<0.01$ ). Regression models listed in equations 6-9 are valid for the ranges of $t_{\text {air }}$ from 24.0 to $35^{\circ} \mathrm{C}$, THI 72.0 to 83.3 , from 72.7 to $84.0 \mathrm{BGHI}$ and $\mathrm{H}$ of 56.5 to $86.7 \mathrm{~kJ} \mathrm{~kg}^{-1}$ dry air, respectively. On the other hand, the values of I should vary between 1 and 14 days. The values of the standard errors of means are presented later to those in the equations specified in parentheses and serve only to indicate the magnitude of the error associated with the adjustment of the constant and should be disregarded in applying the equations.

$$
\begin{aligned}
& \mathrm{t}_{\text {rectal }}=35.03( \pm 0.28)+0.15( \pm 0.009) \cdot \mathrm{t}_{\text {air }}+0.12( \pm 0.003) \text {.age } \\
& \mathrm{t}_{\text {rectal }}=29.01( \pm 0.69)+0.13( \pm 0.009) \cdot \mathrm{THI}+0.12( \pm 0.003) \text {.age } \\
& \mathrm{t}_{\text {rectal }}=27.77( \pm 0.72)+0.14( \pm 0.009) \cdot \mathrm{BGHI}+0.12( \pm 0.003) \text {. age } \\
& \mathrm{t}_{\text {rectal }}=37.44( \pm 0.32)+0.03( \pm 0.004) \cdot \mathrm{H}+0.11( \pm 0.004) \text {.age }
\end{aligned}
$$

The coefficients of determination $\left(\mathrm{R}^{2}\right)$ of equations $6,7,8$ and 9 were 0.73 for the four models proposed and the average absolute errors were $0.32^{\circ} \mathrm{C}, 0.35^{\circ} \mathrm{C}, 0.69^{\circ} \mathrm{C}$ and $0.38{ }^{\circ} \mathrm{C}$, respectively. The average percentage errors were $0.79 \%, 0.86 \%, 1.68 \%$ and $0.94 \%$, the average squared errors of $0.19,0.22,0.59$ and 0.27 and standard deviations were $0.22,0.25,0.49$ and 0.27 , respectively. MEDEIROS et al. (2005b) achieved statistical models for the various physiological responses of adults broilers based on animal behavior in different thermal environments and found values of $\mathrm{R}^{2} 0.98$ for weight gain and feed intake, 0.82 for $t_{\text {rectal }}$ and 0.97 for respiratory frequency, among others. When developing a neuro-fuzzy network to estimate the $t_{\text {rectal }}$ of broilers, FERREIRA (2009) found average squared errors for training and validation equal to 0.20 and 0.24 , respectively. LOPES (2009) found an average percentage error of $0.78 \%$ to $1.02 \%$ for training and validation to train and validate artificial neural networks to predict $t_{\text {rectal }}$ depending on thermal conditions. The comparison of these results in the literature indicates a good accuracy of all adjusted regression models for prediction of $t_{\text {rectal }}$.

\section{Inversion of regression models}

Having the four regression models to estimate the $t_{\text {rectal }}$ and using the methodology proposed by DRAPER \& SMITH (1981) inversion of multilinear regression models can be expected from the $t_{\text {rectal }}$ for each chick age, able to estimate the $t_{\text {air }}$, THI, BGHI and $\mathrm{H}$ that the animal is.

In Figure 3, the dashed lines illustrate the conditions of $t_{\text {air }}$ (a), THI (b) and BGHI (c) recommended by the authors OLIVEIRA et al. (2006) and ABREU \& ABREU (2001) for broiler raising from 1 to 14 days old. 


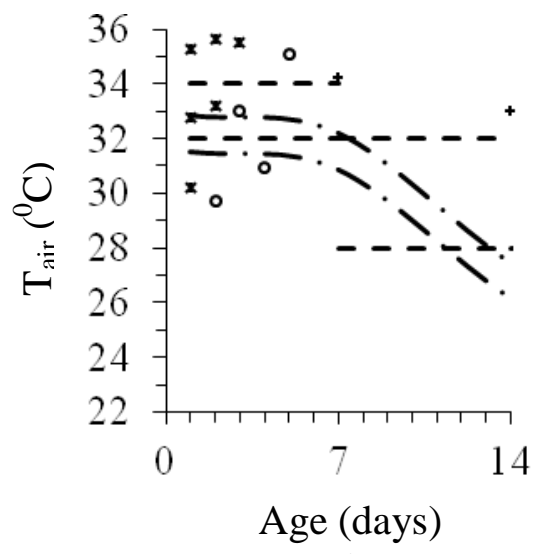

A

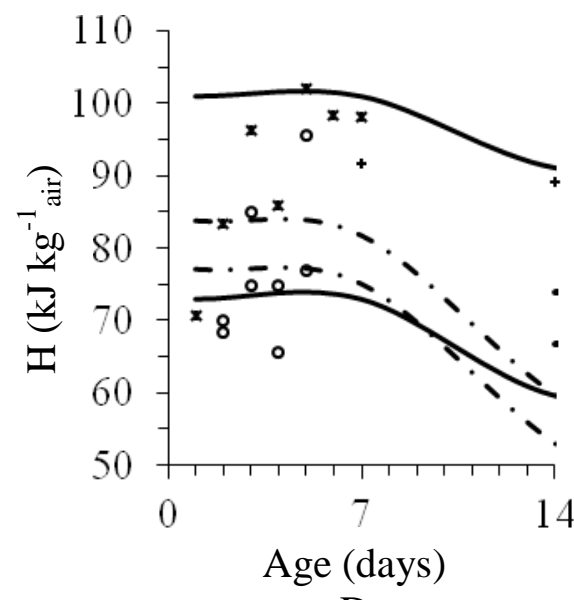

D

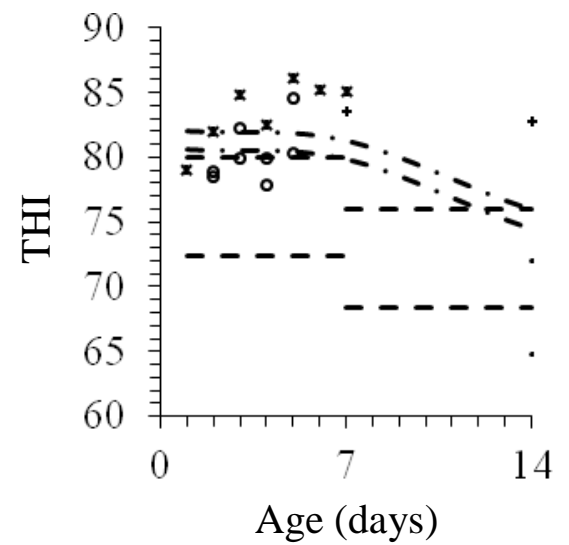

B

* MALHEIROS et al.(2000)

+ IAFIGLIOLA et al. (2000)

o DIONELLO et al. (2002)

_ - - Minimum and maximun limits recomended by literature

- - Estimated limits recomended by MARCHINI et al. (2007)

Limits found based on the $\mathrm{t}_{\text {air }}$ and RH informed by literature

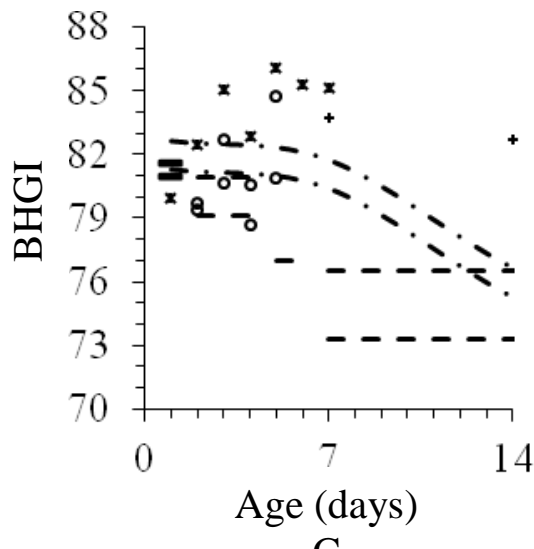

C

FIGURE 3. Profiles of (A) $t_{a i r}$, (B) THI, (C) BGHI and (D) $\mathrm{H}$ recommended by the literature (dashed line), estimated by the reversal of the regression models and $t_{\text {rectal }}$ measured by MARCHINI et al. (2007) (dashed dot line), found based on the $t_{a i r}$ and RH informed by the literature (continuous line) and inverted values of different authors' data (plots).

In the experiment carried out by MARCHINI et al. (2007) chicks raised on the thermal comfort of $\mathrm{t}_{\text {rectals }}$ presented of $40.0 \pm 0.1^{\circ} \mathrm{C}, 40.6 \pm 0.1^{\circ} \mathrm{C}$ and $40.7 \pm 0.1^{\circ} \mathrm{C}$ in the $1^{\text {st }}, 7^{\text {th }}$ and $14^{\text {th }}$ day of life. When using the $t_{\text {rectals }}$ observed by the author and the reciprocals of multilinear regression models, it can find the minimum and maximum $\mathrm{t}_{\mathrm{air}}$, THI, BGHI and $\mathrm{H}$ that these animals should be exposed, which is illustrated by dash lines point in Figure 3.

The chicks $t_{\text {rectal }}$ data of other authors who also studied this same age group (IAFIGLIOLA et al. 2000; MALHEIROS et al., 2000 and DIONELLO et al., 2002) were reversed so they could observe the behavior of the inversion of regression models and are represented by asterisks, crosses and circles in Figure 3.

From Figure 3 (A) it is observed that the values of $t_{\text {air }}$ found in the experiment of MARCHINI et al. (2007) reversing the regression model (equation 6) in the first week is approximately constant until the seventh day of age, and that the $1^{\text {st }}$ to the $14^{\text {th }}$ day coincides with the ideal $t_{\text {air }}$ reported by OLIVEIRA et al. (2006). In the limit recommended by the literature (dashed line) $t_{\text {air }}$ values are fixed per week, but the proposed limits by reversing the chicks $t_{\text {rectals }}$ measured by MARCHINI et al. (2007) show a gradual decrease by the $t_{\text {air }}$ ideal, with a decrease of $t_{\text {air }}$ daily rather than weekly.

Some of the authors' data IAFIGLIOLA et al. (2000), MALHEIROS et al. (2000) and DIONELLO et al. (2002) found them outside the boundaries of literature, as the limits estimated from MARCHINI et al. (2007) data, showing the variation of existing data in the literature for this age group. 
In Figure 3 (B) it is observed the same trend in behavior between the ideal range of THI in the literature (dashed line) and that achieved by inverting the equation 7 based on $t_{\text {rectal }}$ data cited by MARCHINI et al. (2007) (dashed line). In the first days of life, the THI should be higher and decreases with each passing day. But it is observed that the limits of literature are always below the limits estimated by the inversion of the regression models, indicating that they always overestimate the values of THI, but when analyzing data from THI predicted by the inversion of equation 7 with $t_{\text {rectal }}$ data of other authors, it was found that the mesh data is closer than the proposed limits of the limits mentioned in the literature.

BGHI values illustrated in Figure 3 (C) recommended by the literature on the $1^{\text {st }}$ day and the second week of life coincide with the values considered ideal by the inversion of equation 8 based on data from the $t_{\text {rectal }}$ of MARCHINI et al. (2007). In relation to BGHI, the first week of life, the literature recommends fixed values for each two days of life, but there is a big difference between the days. Using the proposed limits by reversing the regression model is a slight variation that occurs daily, indicating that there should be no sudden changes in environmental conditions but subtle modifications to adapt appropriate thermal conditions of the animals.

In the literature, it is observed that the information about the optimal values of $\mathrm{H}$ for broilers is scarce, even more when it comes to chicks. Thus, it was used values of $t_{\text {air }}$ and RH mentioned in the literature as being ideal (OLIVEIRA et al., 2006 and MEDEIROS et al., 2005a) and obtained the limits of comfort for the chicks for $\mathrm{H}$ by the equation proposed by ALBRIGHT (1990), as illustrated in Figure 3 (D) by the continuous line. In the first two weeks, it is observed that both the information from MARCHINI et al. (2007), as that of other authors are within the range proposed as suitable for $\mathrm{H}$ demonstrating the feasibility of using this range as ideal for birds of the $1^{\text {st }}$ to the $14^{\text {th }}$ day of life. This interval is a first attempt to explain what should be the comfort $\mathrm{H}$ to house broiler in the warming up phase. The information available in the literature regarding the thermal conditions suitable for breeding of chicks, as well as data on the variation of their $t_{\text {rectals }}$ are still scarce, indicating the need for further studies, preferably in the laboratory, where they can get better control of experimental conditions, in order to better understand the lower and upper limits of thermal comfort.

\section{CONCLUSION}

It was possible to predict rectal temperature of broilers from 1 to 14 days of age by means of multilinear regression models based on age of animals and a variable weather (air temperature - $t_{\text {air }}$ ) or an index thermal comfort (temperature and humidity index - THI black globe humidity index BGHI) or the physical quantity enthalpy $(\mathrm{H})$, and standard deviations were $0.22,0.25,0.49$ and 0.27 , respectively.

The lower and upper limits of thermal comfort for the enthalpy $(\mathrm{H})$ have been established, even preliminarily, by reversing the regression models.

\section{ACKNOWLEDGMENT}

The authors express their thanks to CAPES, CNPq and FAPEMIG for financial support to this research.

\section{REFERENCES}

ABREU, V. M. N.; ABREU, P. G. Diagnóstico bioclimático para a produção de aves no Oeste paranaense. In: CONGRESSO BRASILEIRO DE ENGENHARIA AGRÍCOLA, 30., 2001, Foz do Iguaçu. Anais... Foz do Iguaçu: UNIOESTE/SBEA, 2001. 1 CD-ROM.

ALBRIGHT L. D. Environment control for animals and plants. St. Joseph: American Society of Agricultural Engineers Michigan, 1990. (ASAE Textbook, 4). 
BARBOSA FILHO, J. A. D.; SILVA, I. J. O.; SILVA, M. A. N.; SILVA, C. J. M. Avaliação dos comportamentos de aves poedeiras utilizando sequência de imagens. Engenharia Agrícola, Jaboticabal, v. 27, n.1, p. 93-99, jan./abr. 2007a .

BARBOSA FILHO, J.A.D.; VIEIRA, F.M.C.; GARCIA, D.B. SILVA, M.A.N.; SILVA, I.J.O. Mudanças e uso das tabelas de entalpia. Piracicaba, 2007. Disponível em:

<http://www.nupea.esalq.usp.br>. Acesso em: 10 fev. 11.

BUFFINGTON, D.E.; COLLASSO-AROCHO, A.; CANTON, G.H. et al. Black globe-humidity index (BGHI) as comfort equation for dairy cows. Transaction of the ASAE, St. Joseph, v.24, p.711714, 1981.

CORDEIRO, M.B.; TINÔCO, I. de F.F.; SILVA, J.N da; VIGODERIS, R.B.; PINTO, F.de A.de C.; CECON, P.R. Conforto térmico e desempenho de pintos de corte submetidos a diferentes sistemas de aquecimento no período de inverno. Revista Brasileira Zootecnia, Viçosa-MG, v.39, n.1, p.217-224, jan. 2010.

DAMASCENO, F. A.; YANAGI JUNIOR, T.; LIMA, R. R. de; GOMES, R. C. C.; MORAES, S. R. P de. Avaliação do bem-estar de frangos de corte em dois galpões comerciais climatizados. Ciência \& Agrotecnologia, Lavras, v.34, n.4, ago. 2010 .

DIONELLO, N. J. L.; MACARI, M.; FERRO, J. A.; RUTZ, F.; FERRO, M. I. T.; FURLAN, L.R. Respostas Fisiológicas Associadas à Termotolerância em Pintos de Corte de Duas Linhagens por Exposição a Altas Temperaturas. Revista Brasileira de Zootecnia, Viçosa, v.31, n.1, p.79-85, 2002.

DRAPER, N.; SMITH H. Applied regression analysis. New York: John Wiley \& Sons, 1981. 407p.

FERREIRA, L. Aplicação de sistemas fuzzy e neuro-fuzzy para predição da temperatura retal de frangos de corte. 2009. 56f. Dissertação (Mestrado em Engenharia de Sistemas) - Universidade Federal de Lavras, Lavras, 2009.

FUNCK, S.R.; FONSECA, R.A.. Avaliação energética e de desempenho de frangos com aquecimento automático a gás e a lenha. Revista brasileira de engenharia agrícola e ambiental, Campina Grande, v.12, n.1, p.91-97, fev. 2008.

FURTADO, D. A.; ROCHA, H. P.; NASCIMENTO, J. W. B.; SILVA, J. H. V.. Índices de conforto térmico e concentração de gases em galpões avícolas no semiárido Paraibano. Engenharia Agrícola, Jaboticabal, v. 30, n. 6, p. 993-1002. Dez. 2010.

IAFIGLIOLA, M. C.; MENTEN, J. F. M.; ROCANICCI, A. M. C.; GAIOTTO, J. B. Cobre e Antibiótico como Promotores de Crescimento em Rações para Frangos de Corte. Revista Brasileira de Ciência Avicola, Campinas, v. 2, n. 3, 201-208p. Set. 2000.

LOPES, A. Z. Desenvolvimento de um neuro-controlador para galpões climatizados de frangos de corte. 2009. 140f. Dissertação (Mestrado em Engenharia de Sistemas - Modelagem e Análise de Sistemas) Universidade Federal de Lavras, Lavras, 2009.

MALHEIROS, R. D. ; MORAES, V.M.B. ; BRUNO, L. D. G. ; MALHEIROS, E. B. ; FURLAN, R. L. ; MACARI, M. . Environmental temperature and cloacal surface temperatures of broiler chicks in first week post-hatch. Journal of Applied Poultry Research, Champaign, v. 9, n.1, p. 111$117,2000$.

MARCHINI, C.F.P.; SILVA, P.L.; NASCIMENTO, M.R.B.M; TAVARES, M. Frequência respiratória e temperatura cloacal em frangos de corte submetidos à temperatura ambiente cíclica elevada. Archives of Veterinary Science, Curitiba, v.12, n.1, p.41-46, jan./mar. 2007.

MEDEIROS, C.M.; BAETA, F.C.; OLIVEIRA, R.F.M. TINÔCO, I. F. F.; ALBINO, L. F. T.; CECON, P. R.. Efeitos da temperatura, umidade relativa e velocidade do ar em frangos de corte. Engenharia na Agricultura, Viçosa-MG, v.13, n.4, p.277-286, out./dez. 2005a. 
MEDEIROS, C.M.; BAETA, F.C.; OLIVEIRA, R.F.M. TINÔCO, I. F. F.; ALBINO, L. F. T.; CECON, P. R.. Índice térmico ambiental de produtividade para frangos de corte. Revista Brasileira de Engenharia Agrícola e Ambiental, Campina Grande, v. 9, n. 4, p. 660-665, dez. 2005b.

MOURA, D.J.; BUENO, L.G.F.; LIMA, K.A.O de, CARVALHO, T.M.R. de, MAIA, A.P.A.M.. Strategies and facilities in order to improve animal welfare. Revista Brasileira de Zootecnia Viçosa, v.39, p. 311-316, 2010. Suplemento especial.

OLIVEIRA, R. F. M.; DONZELE, J. L.; ABREU, M. L. T.; FERREIRA, R. A.; VAZ, R. G. M. V.; CELLA, P. S. Efeitos da temperatura e da umidade relativa sobre o desempenho e o rendimento de cortes nobres de frangos de corte de 1 a 49 dias de idade. Revista Brasileira de Zootecnia, ViçosaMG, v.35, n.3, p.797-803, maio/jun. 2006.

R DEVELOPMENT CORE TEAM. R: A Language and Environment for Statistical Computing. Vienna: R Foundation for Statistical Computing, 2007. Disponível em: <www.R-project.org. Version 2.3.1>. Acesso em: 05 fev. 2011.

ROCHA, H. P. da; FURTADO, D. A.; NASCIMENTO, J.W. B. do; SILVA, José H. V.. Índices bioclimáticos e produtivos em diferentes galpões avícolas no semiárido paraibano. Revista Brasileira de Engenharia Agrícola e Ambiental, Campina Grande, v.14, n.12, dez. 2010.

RODRIGUES, V. C.; SILVA, I. J. O.; VIEIRA, F. M. C.; NASCIMENTO, S. T. A correct enthalpy relationship as thermal comfort índex for livestock. International Journal Biometeorology, Berlim, v. 55, n. 3, p. 455-459, jul. 2010.

SANTOS, P. A. dos; BAÊTA, F. C.; TINÔCO, I. F. F.; ALBINO, L. F. T.; CECON, P. R.. Avaliação dos sistemas de aquecimento a gás e a lenha para frangos de corte. Revista Ceres, Viçosa-MG, v.56, n.01, p. 09-17, jan./ fev. 2009.

SILVA, M. A. N.; ROSÁRIO, M. F.; HELLMEISTER FILHO, P.; COELHO, A. A. D.; SAVINO, V. J. M.; SILVA, I. J. O.; MENTEN, J. F. M. Influência do sistema de criação sobre o desempenho, a condição fisiológica e o comportamento de linhagens de frango de corte. Revista Brasileira de Zootecnia, Viçosa, v.32, n.1, p.208-213, jan./fev. 2003.

THOM, E. C. The discomfort index. Weatherwise, Boston, v. 12, n. 1, p. 57-60, 1959. 